\title{
A indenização no caso de danos ocorridos no transporte aéreo: a responsabilidade contratual e extracontratual do Código Brasileiro de Aeronáutica em face do atual Código de Defesa do Consumidor*
}

\author{
Marcelo Domanski**
}

\begin{abstract}
Sumário: Introdução: 1. O Código Brasileiro De Aeronáutica e as Convenções Internacionais; 2. Aeronave; 2.1. Conceito Legal; 2.2. Classificação; 3. Noções Acerca do Contrato de Transporte Aéreo no Código Brasileiro de Aeronáutica; 4. A Responsabilidade Civil do Transportador Aeronáutico no Código Brasileiro de Aeronáutica e no Código de Defesa do Consumidor; 4.1. Procedimento de Habilitação Extrajudicial no Caso de Dano: 4.2. A Indenização no Caso de Dano ao Passageiro: 4.3. Obrigação Reajustável do Tesouro Nacional; 4.4. A Indenização no Caso de Danos à Bagagem; 4.5. A Indenização no Caso de Danos à Carga; 4.6. A Indenização no Caso de Serviço Aéreo Gratuito: 4.7. A Indenização para com Terceiros na Superfície; 4.8. A Indenização no Caso de Abalroamento; 5. A Responsabilidade do Construtor Aeronáutico e das Entidades de Infra-Estrutura Aeronáutica: 6. A Garantida da Responsabilidade e Respectiva Indenização: 7. A Responsabilidade no Transporte Aéreo Internacional; 8. Conclusão.
\end{abstract}

\section{Introdução}

Há áreas da atividade humana que recebem, dada a existência de uma legislação especial, uma disciplina jurídica própria e específica. Por esta razão as normas gerais do Direito Civil não se aplicam. No campo da

* Monografia apresentada à Disciplina de Instituições Fundamentais de Direito Civil no Curso de Pós-Graduação em Direito da Universidade Federal do Paraná. sob a orientação do Professor Dr. João Casillo.

** Mestrando no CPGI)/UJPR.

R. Fac. Direito. Curitiba, a.27. n.27. 1992/93. p.103-139 
responsabilidade civil destaca-se a responsabilidade do transportador aeronáutico, que recebeu tratamento diferenciado.

Entretanto, a introdução de novas normas no ordenamento jurídico têm muitas vezes o efeito de revogar, expressa ou tacitamente, ou ab-rogar, derrogar normas anteriormente existentes neste mesmo ordenamento. Disciplinadoras da mesma matéria, a lei posterior revoga a anterior quando expressamente a declare, quando seja com ela incompatível ou quando regule inteiramente a matéria de que tratava a lei anterior $\S 1^{\circ}$ do art. $2^{\circ}$ da Lei de Introdução ao Código Civil (LICC). Por outro lado, lei nova que estabelece disposições gerais ou especiais a par das já existentes, não revoga nem modifica a lei anterior .

Face à entrada em vigor da Lei $n^{\circ} 8.078$, de 11/09/90, que instituiu o Código de Defesa do Consumidor (CDC) e analisando-o em conjunto com os dispositivos da Lei $\mathrm{n}^{\circ} 7.565$ de 19 de dezembro de 1986 , denominado de Código Brasileiro de Aeronáutica (CBA), suscitam-se algumas dúvidas acerca da derrogação de várias normas deste último diploma legal, principalmente no que se refere aos dispositivos disciplinadoras da responsabilidade civil, objeto deste estudo.

É fundamental esclarecer se efetivamente ocorreram e quais foram as principais alterações no CBA em face da disciplina da responsabilidade do fornecedor de produtos e serviços no CDC, notadamente no que diz respeito ao estabelecimento do quantum indenizatório.

\section{O Código Brasileiro de Aeronáutica e as Convenções Internacionais}

Até anteriormente a entrada em vigor do CDC, a responsabilidade do transportador aeronáutico, prestador do serviço de transporte aéreo, foi objeto de regulamentação por diversas Convenções Internacionais das quais - Brasil é signatário, notadamente a Convenção de Varsóvia, promulgada pelo Decreto ${ }^{\circ} 20.704$, de 24 de novembro de 1934 .

As convenções e tratados internacionais, em matéria de responsabilidade civil, disciplinaram a responsabilidade objetiva do transportador aeronáutico, juntamente com o tarifamento da indenização no caso de danos pessoais e materiais, principalmente em decorrência de dois fatores: 
a) a necessidade de proteger a parte mais fraca da relação jurídica, que teria grandes dificuldades em provar a causa do acidente bem como a culpa do agente para obter o respectivo ressarcimento:

b) garantir ao transportador aéreo, em atividade ainda incipiente, principiante, um teto nas indenizações por acidentes para lhe permitir organizar a sua atividade e atrair investimentos.

Neste mesmo sentido foi a orientação adotada pelo CBA. Precisamos entretanto esclarecer se o contido nestes tratados ainda vigora no Brasil, tendo em conta que a terminação dos Tratados Internacionais, ao contrário do que ocorre com as demais normas jurídicas, pode se dar, de acordo com Hildebrando Accioly, através das seguintes formas:

a) execução integral do tratado;

b) expiração do prazo convencionado;

c) verificação de condição resolutória expressamente prevista;

d) da vontade comum das partes contratantes, ainda que o seu objetivo não se tenha realizado ou seu prazo de duração não tenha esgotado;

e) da denúncia, ato pelo qual uma das partes contratantes comunica à(s) outra(s) a sua intenção de dar por findo o tratado ou se retirar do mesmo;

f) celebração de outro tratado regulando diversamente a matéria anteriormente disciplinada;

g) a impossibilidade de execução por caso fortuito ou força maior;

h) $\mathrm{a}$ inexecução em si do tratado ${ }^{1}$

Verifica-se assim, que os tratados relativos à responsabilidade do transportador aéreo ratificados anteriormente a entrada em vigor do Código de Defesa do Consumidor, ainda são aplicáveis, continuam em plena vigência, eis que ainda não configuradas quaisquer das hipóteses acima enumeradas.

1 Hildebrando Accioly, Manual de Direito Internacional Público, São Paulo, Saraiva, 1986, p. 134 e ss.

R. Fac. Direito, Curitiba, a.27, n.27, 1992/93, p.103-139 
Resta saber se em função da entrada em vigor do $\mathrm{CDC}$, o tarifamento da indenização previsto no CBA e demais tratados internacionais de que o Brasil é signatário, ainda vigora, bem como se há eventuais alterações.

A entrada em vigor de uma disciplina jurídica específica das relações de consumo suscita reflexões sobre a responsabilidade civil aeronáutica, que no âmbito nacional está regulamentada de maneira especial no Título VIII, Capítulo I, Seções I a V, Capítulos II a VII, do CBA, e que será analisado a seguir.

\section{Aeronave}

\subsection{Conceito legal}

Não é possível estudar a responsabilidade civil aeronáutica sem antes estabelecer um entendimento do que seja aeronave. A primeira noção portanto, o conceito fundamental a partir do qual o jurista poderá iniciar o seu estudo acerca da matéria é definir, ou ao menos procurar estabelecer o que se entende pelo termo aeronave.

O CBA no art. $106 \S$ único, estabeleceu um conceito para o termo aeronave, nos seguintes termos: Considera-se aeronave todo aparelho manobrável em vôo, que possa sustentar-se e circular o espaço aéreo, mediante reações aerodinâmicas, apto a transportar pessoas ou coisas, constituindose em um bem móvel, registrável para o efeito de nacionalidade, matrícula, aeronavegabilidade ( art. 72, inciso I, art. 109 e art. 114, transferência por ato entre vivos; art. 72 , inciso II e art. 115, inciso IV, constituição de hipoteca; art. 72, inciso II e art. 138, publicidade; art. 72, inciso III e art. 117 e cadastramento geral; art. 72, inciso V).

O conceito de aeronave transcrito acima é bastante abrangente, englobando os ultraleves e os planadores, eis que tem como requisitos as seguintes características:

a) todo aparelho manobrável em vôo;

b) apto a se sustentar e circular no espaço; 
c) mediante ações aerodinâmicas;

d) que transporte pessoas ou coisas.

Faltando um dos elementos acima, não se tratará de aeronave. Caberia então a dúvida: asa-delta pode ser considerada uma aeronave? É um aparelho manobrável, porém nem sempre em toda direção, capaz de circular no espaço aéreo. Porém não é capaz de se auto-sustentar em qualquer situação ou em todo espaço, haja vista depender de um plano elevado do qual possa decolar, bem como dos ventos para poder se sustentar, razão pela qual não a consideramos uma aeronave.

Há quem prefira, pelos motivos acima e face ao estabelecido no $\$ 3^{\circ}$ do art. 268 do CBA, delimitar o conceito de aeronave, entendendo-o como o aparelho capaz de se auto-elevar do solo por meio de sua própria força motriz, ou mecanismos, e de se manter e circular no espaço aéreo tendo em vista reações aerodinâmicas, adequado para o transporte de pessoas ou objetos. Neste caso estariam excluídos do conceito os planadores.

Entretanto, de acordo com o caput do art. 106 combinado com o $\$ 4^{\circ}$ do art. 268 do CBA, o ultraleve e o planador devem ser considerados aeronaves, eis que preenchem todos os requisitos mencionados, o mesmo não ocorrendo com a asa-delta, já que o âmbito de circulação no espaço aéreo é restrito, não podendo circular em toda e qualquer direção.

\subsection{Classificação}

O Código Brasileiro de Aeronáutica, no art. 107 e seus parágrafos classificou as aeronaves em:

a) aeronaves civis, subdivididas em:

a.1) públicas: as destinadas ao serviço do Poder Público (Administração Direta Federal, Estadual, e Municipal) inclusive as requisitadas na forma da lei;

a.2) privadas: todas as demais, incluídas aquelas a serviço de entidades da Administração Indireta Federal, Estadual ou Municipal.

b) militares: relativamente às quais não se aplicam as disposições do Código Brasileiro de Aeronáutica. 


\section{Noções acerca do contrato de transporte aéreo no Código Brasileiro de Aeronáutica}

O contrato de transporte aéreo é o instrumento pelo qual obriga-se o empresário, dono de aeronave, a transportar o passageiro, bagagem, carga, encomenda ou mala postal, por meio de aeronave e mediante uma remuneração ou pagamento, conforme art. 222 do CBA.

Geralmente se apresenta sob a modalidade de contrato de adesão, ou seja, o seu conteúdo é estabelecido pelo transportador cabendo à outra parte aceitar ou não a totalidade das cláusulas estabelecidas, eliminada a livre discussão que precede normalmente a formação dos contratos.

O empresário transportador pode ser pessoa física ou jurídica, proprietário ou explorador da aeronave.

São características do contrato de transporte:

a) é contrato bilateral, em que há obrigações para ambas as partes;

a. 1.) do transportador em prestar o serviço de transporte contratado;

a.2.) do usuário ou beneficiário em pagar o valor da tarifa, ou seja, o preço da passagem no transporte de pessoas ou o frete da carga ou mala postal.

b) é contrato consensual, conclui-se com o ajuste das partes:

c) a onerosidade é elemento essencial. O preço da passagem e do frete é obrigatório.

No caso de transporte gratuito ou por cortesia, a responsabilidade civil é tratada fora do âmbito contratual, conforme art. 267 do CBA.

Importante ressaltar o contido no art. 223 do CBA, que dispõe haver um só contrato de transporte, quando ajustado num único ato jurídico, por meio de um ou mais bilhetes de passagem, ainda que executado, sucessivamente, por mais de um transportador.

Conforme doutrina José da Silva Pacheco, quando o cliente procura uma empresa de transporte aéreo, no Rio de Janeiro, e contrata com ela a sua condução para determinado lugar, a Pequim, por exemplo, via pontos intermediários nos Estados Unidos, na Europa ou no Oriente, pouco importa quantos bilhetes de passagem a empresa emitir, ou quem efetivamente vá 
realizá-lo nos segmentos onde aquela empresa não opere. O certo é que existe um só contrato de transporte entre aquela empresa e o passageiro. ${ }^{2}$ Trata-se de norma que já constava do Código Brasileiro do Ar e igualmente da Convenção de Varsóvia.

O art. 224 do CBA prevê a hipótese de transporte combinado, assim entendido em que há além do transporte através de aeronave, aquele realizado por outro meio, veículo automotor, navio, trem. Nesta hipótese, aplicase, no que se refere ao transporte aéreo o disposto no CBA.

Por outro lado, considera-se transportador, o que de fato realiza todo o transporte ou parte dele, presumidamente autorizado pelo transportador contratual e sem se confundir com ele ou com o transportador sucessivo, art. 225 do CBA.

Assim, transportador contratual é aquele que se obrigou, mediante contrato, a realizar o transporte e o realiza, diretamente. É como se determinada companhia, que vendeu passagem de transporte do Rio de Janeiro para Paris, executa o contrato normalmente.

Sucessivo é o transportador que executa o trecho seguinte ao realizado pelo transportador contratual, na hipótese de ter o contrato de transporte de ser executado por mais de um transportador. É o caso da empresa que vende a passagem Rio de Janeiro - Moscou, realizando o trecho Rio-Paris, entregando segmento seguinte a outra companhia que o opera. Este último é considerado transportador sucessivo, não obstante haja um único contrato de transporte.

Transportador de fato é o que realiza todo o transporte ou parte dele, presumidamente autorizado pelo contratual, mas sem se confundir com ele ou com o sucessivo. Quando o transporte for contratado com um transportador e executado por outro, no caso de responsabilidade civil, pode-se demandar tanto o transportador contratual como o de fato.

A falta, a irregularidade ou a perda do bilhete de passagem, nota de bagagem e conhecimento de carga não prejudica a existência e a eficácia do contrato de transporte aéreo, consoante art. 226 do CBA.

O bilhete de passagem, a nota de bagagem e o conhecimento de carga comprovam a existência do contrato de transporte, e são de emissão obri-

2 José da Silva Pacheco, Comentários ao Código Brasileiro de Aeronáutica, Rio de Janeiro, Forense, 1990: p. 440.

R. Fac. Direito. Curitiba. a.27, n.27. 1992/93, p.103-139 
gatória por parte do transportador, a sua perda ou irregularidade não prejudica a existência e a eficácia do referido contrato, se por outros meios puder ser comprovado. Assim, se em acidente tais documentos se danificarem, tal fato não prejudica a existência do contrato, tanto em favor do passageiro como do expedidor, ou como do transportador.

\section{A responsabilidade civil (contratual e extracontratual) do transportador aeronáutico no Código Brasileiro de Aeronáutica e no Código de Defesa do Consumidor}

Em um primeiro plano, verifica-se que nos encontramos no campo da responsabilidade contratual, oriunda do contrato de transporte que há entre o passageiro e a empresa aérea ou o transportador, o qual se caracteriza por três elementos essenciais:

a) a existência do contrato;

b) a sua inexecução culposa;

c) a causação, ou a origem de um dano.

No sistema do Código Civil, a regra básica no que se refere à responsabilidade contratual é a do art. 1.056, que estabelece que não cumprindo a obrigação ou deixando de cumpri-la no tempo e modo devidos, responde o devedor por perdas e danos.

O CBA adotou a teoria da responsabilidade objetiva ${ }^{3}$. Esse entendimento é corroborado principalmente face à entrada em vigor do $\mathrm{CDC}$, que estabeleceu expressamente no art. 14, que o fornecedor de serviços re-

() nosso ordenamento juridico conhece:

a) responsabilidade subjetiva: é a de regra geral. onde o prejudicado deve comprovar. com suficiência. ter o agente agido com culpa em sentido lato. isto é. como dolo ou culpa em sentido estrito (negligència. imprudència e impericia):

b) responsabilidade objetiva: que se estrutura independentemente de culpa e em que o único nexo causal exigível é o que vincula. fisicamente. a conduta do agente e o resultado danoso conseqüente, com base na teoria do risco:

c) a responsabilidade por culpa presumida: ou com a inversão do ònus da prova da culpa. em que a excludência da responsabilidade depende. em tese, do agente provar que não agiu com culpa. 
sponde, independentemente da existência de culpa, pela reparação dos danos causados aos consumidores por defeitos relativos à prestação dos serviços.

A prova do não cumprimento da obrigação, prestação do serviço de transporte aéreo, ou o seu cumprimento defeituoso, implica na responsabilidade objetiva por parte do fornecedor do serviço, exonerando-se unicamente se provar que o transporte foi regularmente efetuado ou a culpa exclusiva do consumidor ou de terceiro, conforme incisos I e II do $\S 3^{\circ}$ do art. 14 do CDC.

Extremamente importantes são as disposições dos artigos 25 e 51 do diploma legal de tutela da relação de consumo, ao estabelecerem, respectivamente, ser vedada a estipulação contratual que impossibilite, exonere ou atenue a obrigação de indenizar prevista no código, assim como qualifica de nulidade as cláusulas relativas ao fornecimento de produtos ou serviços que impossibilitem, exonerem ou atenuem a responsabilidade do fornecedor pelo vícios de qualquer natureza dos produtos e serviços ou impliquem na renúncia de direitos, reconhecendo que nas relações de consumo entre o fornecedor e o consumidor pessoa jurídica, a indenização poderá ser limitada em situações justificáveis.

Infere-se dos termos acima, não está proibida ao legislador, a limitação de valores das indenizações nos casos de responsabilidade por danos pessoais ou materiais, nas hipóteses em que este entender conveniente, ou melhor, justificáveis. Impede entretanto, que por vontade das partes contratantes, sejam formuladas cláusulas contratuais que impossibilitem, exonerem ou atenuem a responsabilidade.

Não existe portanto, proibição alguma por parte do CDC, que lei especial estabeleça limitação ao dever de indenizar, ou seja, institua o tarifamento ḍa indenização. Esta proibição limita-se ao contrato celebrado entre as partes da relação de consumo.

Neste sentido a Convenção de Varsóvia é cristalina, ao estabelecer no art. 23, serem nulas, de pleno direito, as cláusulas tendentes a exonerar o transportador de sua responsabilidade, ou estabelecer limite inferior ao que the fixa a convenção. Idêntica disposição contém o CBA em seu art. 247.

Qualquer cláusula do contrato de transporte que tenha por objetivo exonerar a responsabilidade do transportador ou estabelecer limites de

R. Fac. Direito. Curitiba. a.27. n.27, 1992/93. p.103-139 
indenização inferiores aos limites previstos no CBA são nulas, o que não acarreta a nulidade do contrato que continuará disciplinado supletivamente pelo CBA e pelo CDC.

Consoante autoriza o $\S 1^{\circ}$ do art. 257 do CBA, nada impede que as partes contratantes estabeleçam, mediante pacto acessório, um limite maior ao valor da indenização que o estabelecido em lei. Isso não significa se esteja atenuando a responsabilidade do fornecedor de serviços. Muito pelo contrário, eis que existe um tarifamento previsto pela lei, não proibido expressa ou tacitamente pelo Código do Consumidor, nada havendo que impeça que as partes estabeleçam um limite indenizatório maior no caso de acidente, que por óbvio não pode ser considerado como atenuação da responsabilidade, mas de mera disposição, do exercício da autonomia da vontade das partes dentro dos parâmetros legais.

Verifica-se portanto, que o tarifamento da indenização, limitando a responsabilidade do transportador aeronáutico continua plenamente em vigor, paralelamente aos dispositivos do CDC, somente devendo ser excluído quando houver dolo ou culpa grave do transportador ou dos prepostos, requisitos previstos no CBA. Pela sua importância, transcreve-se a seguir os termos do art. 248 e seus parágrafos:

Art. 248. Os limites de indenização, previstos neste Capítulo, não se aplicam se for provado que o dano resultou de dolo ou culpa grave do transportador ou de seus prepostos.

$\$ 1^{\circ}$ Para os efeitos deste artigo, ocorre o dolo ou a culpa grave quando o transportador ou seus prepostos quiseram o resultado ou assumiram o risco de produzi-lo.

$\$ 2^{\circ} \mathrm{O}$ demandante deverá provar, no caso de dolo ou culpa grave dos prepostos, que estes atuavam no exercício de suas funções.

$\leqslant 3^{\circ}$ A sentença, no Juizo Criminal, com trânsito em julgado, que haja decidido sobre a existência do ato doloso ou culposo e sua autoria, será prova suficiente.

Anteriormente à edição do Código Brasileiro do Ar - 1938 - e do CBA, disciplinava a Convenção de Varsóvia, em seu art. 25 que o transportador não teria direito de se prevalecer das disposições da Convenção que excluem ou limitam a responsabilidade, tarifamento, se o dano provém de dolo ou de uma falta causada pelos prespostos do transportador no exercício 
de suas funções que, de acordo com a lei do tribunal que conhecer da questão, é considerada como equivalente ao dolo.

Verifica-se que a Convenção deixou ao direito nacional de cada país a definição do conceito de dolo bem como da falta que pudesse ser considerada equivalente ao mesmo, do que resultaram interpretações divergentes não só entre todos os países signatários da Convenção, o que não era desejado, mas também entre os tribunais nacionais.

Para corrigir o erro cometido foi assinado o protocolo de Haia de 1955, que estabeleceu o conceito de dolo como sendo o dano resultante de uma ação ou omissão do transportador ou seus prepostos, com a intenção de causar dano ou negligentemente, com a consciência de que o dano provavelmente ocorreria.

Como bem assinala a Dra. Nádia de Araújo, anteriormente à entrada em vigor do $\mathrm{CBA}$, o legislador brasileiro não incorporou para os casos domésticos a definição dada ao conceito de dolo pelo referido protocolo, continuando a seguir a Convenção de Varsóvia antes de sua emenda ${ }^{4}$. Desse modo, era quase impossivel a exoneração do limite previsto no Código Brasileiro do Ar, dado que para a ocorrência de um ato doloso, intencional, na maioria das vezes só seria possivel quando o transportador ou o preposto desejasse a própria morte.

Se no Direito Brasileiro o protocolo de Haia não teve repercussão, na França os tribunais passaram a interpretar o dolo como sendo uma falta indesculpável, ou seja, havia a presunção por parte do julgador de que em determinada situação seria impossível considerar que o piloto não sabia dos riscos que estava assumindo ou da probabilidade da ocorrência de danos.

No Brasil, ainda de acordo com a doutrina da Dra. Nádia, o conceito de dolo no direito civil é atualmente mais amplo que no passado, eis que para a sua caracterização não é mister se perquirir se o agente teve 0 propósito de causar o mal, basta verificar se procedeu consciente de que o seu comportamento poderia ser lesivo ${ }^{5}$. Na culpa grave o autor do dano, sem o querer, comportou-se como se o tivesse querido, desejado.

4 Nádia de Araújo, "A responsabilidade civil no transporte aéreo: direito brasileiro". Revista Forense, Rio de Janeiro. Forense. v. 318. p. 129.

5 Interessante transcrever a posição de José da Silva Pacheco. Comentários..., op. cit., p. 493: "Embora, no passado remoto encontrem-se equiparações da culpa lata ao dolo (culpa lata dolo aequiparatur, proper dolum est). o certo é que. hoje em dia, no campo

R. Fac. Direito. Curitiba, a.27.n.27. 1992/93. p.103-139 
Verifica-se portanto, que o tex to do CBA equipara o conceito de dolo ao de culpa grave, e este com aquele. Assim sempre que ficar comprovado que o transportador quis o resultado danoso, ou assumiu conscientemente o risco de produzi-lo, ou seja, tinha consciência da grande probabilidade de sua ocorrência.

Conforme doutrina José da Silva Pacheco:

"A primeira parte do $\S 1^{\circ}$ do art. 248 do CBA adotou a teoria da vontade, ao assinalar a ocorrência do dolo quando o transportador ou o preposto quis o resultado danoso. Neste caso os agentes devem conhecer osÿatos que praticaram e sua significação contrária às normas, e devem estar dispostos, deliberadamente, a produzir o resultado danoso.

Na segunda parte do $\S 1^{\circ}$ do art. 248 do CBA apresenta-se a teoria do assentimento, uma vez que exige a previsão do resultado como provável, a consciência da irregularidade da conduta e o manifesto em assumir o risco."

Diante do acima exposto, podem ser considerados atos que implicam em culpa grave do piloto: desrespeito às determinações da torre de comando, ou seja, apesar de orientado e advertido pela torre de controle de aeroporto para sair da rota de outro avião, desrespeita a ordem e vem a colidir com a aeronave; o ato de o piloto desobedecer ordem da torre para pousar em outro aeroporto, ou esperar instruções, e que decide tentar aterrissagem assim mesmo, vindo em razão disso a causar acidente aéreo.

O legislador nacional, portanto, através do art. $248, \S 1^{\circ}$ do CBA, equiparou o conceito de culpa grave ao de dolo. Nestas hipóteses fica excluída a indenização tarifária prevista no CBA, para se aplicarem as normas pertinentes à matéria constantes do Código Civil. Acerca da aplicação prática do art. 248 o Tribunal de Justiça do Mato Grosso do Sul já teve a oportunidade de se pronunciar em ação de perdas e danos em virtude de falecimento ocorrido em acidente aéreo:

Em acidente aéreo fatal, provada a culpa grave do comandante da aeronave, preposto da transportadora, deve esta ressarcir os danos, mesmo que os

familiares da vítima tenham recebido o seguro obrigatório. Se o causador jurídico. força é acentuar. antes de tudo. a impossibilidade do conceito de dolo poder corresponder ao de culpa grave. Esta não é dolo. e tanto assim que o característico da prova da má-fé encontrado neste. não se acha encontrado na outra."

"José da Silva Pacheco. Comentários..., op. cit.. p. 494. 
do acidente obrou com dolo ou culpa grave, a indenização deve ser mais ampla que a tarifária, compondo-se o dano pelas regras do Direito Comúm. A Lei $n^{\circ} 7.565$, no seu art. 248 manda que sejam desprezados os limites da indenização nela previstos, se demonstrado que o dano resultou de dolo ou culpa grave do transportador ou de seus prepostos. Apelação Cível n. 541/87. Relator: Romulo Letteriello. j. em 02.09.87, publicada em Jurisprudência Brasileira, 134, ps. 64/69. In Revista Forense, vol. 318, p. 134.

Ficou configurada a culpa grave do piloto, no acórdão acima, pelo fato de que o comandante tentou pousar no aeroporto de Tabatinga, em Mato Grosso do Sul, quando este se encontrava completamente fechado para qualquer tipo de operação em razão de nevoeiro. Por essa razão, entendeu o Tribunal que a indenização não poderia sofrer a limitação prevista pelo CBA, aplicando-se o disposto no art. 248, combinado com as disposições do Código Civil para estabelecer o quantum debeatur da indenização.

Importante salientar que os valores apontados como limite de responsabilidade não abrangem os honorários de advogado e despesas judiciais as quais somente serão devidas se houver processo judicial, sucumbência ou condenação.

\subsection{Procedimento de habilitação extrajudicial nos casos de dano}

O CBA estabelece a instauração de um procedimento de habilitação extrajudicial, no prazo de 30 dias a partir da data em que a aeronave deveria chegar ao ponto de destino, ou da interrupção do transporte, para que o interessado se habilite ao recebimento da respectiva indenização.

$\mathrm{O}$ interessado, desde que tenha direito à reparação, deve habilitar-se portanto, perante a empresa transportadora ou seguradora, mediante a comprovação simples do acidente, do dano decorrente, e da legitimidade. Se o acidente e o dano forem notórios, ou reconhecidos pela transportadora, não haverá necessidade de prová-los. O seguro não precisa ser provado, eis que é obrigatório, deve existir, sob pena de responsabilidade da transportadora.

Se o interessado não puder se habilitar no prazo acima, nem por isso perderá o direito, podendo habilitar-se a qualquer momento, dentro do prazo prescricional de 2 anos. Para os que não se habiltarem tempestivamente, seja em virtude da impossibilidade do cumprimento de exigências legais ou

R. Fac. Direito. Curitiba, a.27, n.27, 1992/93, p.103-139 
não, o pagamento deverá ocorrer nos trinta dias posteriores à habilitação ou satisfação das exigências legais.

No prazo de 30 dias seguintes, o responsável deverá efetuar aos habilitados os respectivos pagamentos com recursos próprios ou provenientes do seguro, mediante recibo de quitação. Para aqueles que se habilitaram mas não provaram suficientemente a sua qualidade e legitimidade, deixando de cumprir as exigências legais a respeito, somente trinta dias após o cumprimento destes requisitos é que terão direito a receber o devido o pagamento.

Esgotados os períodos estabelecidos acima, poderá o prejudicado promover judicialmente, pelo procedimento sumaríssimo, a reparação do dano, nas seguintes hipóteses:

a) inadimplemento da obrigação positiva e líquida ao interessado tempestivamente habilitado;

b) apesar de habilitado fora do prazo, o responsável não pagar nos trinta dias seguintes à habilitação intempestiva;

c) a constatação da iliquidez do quantum debeatur da indenização;

d) a falta de comprovação relativamente ao fato, ao dano, ou a relação de causa e efeito, devendo ser apurada em procedimento sumaríssimo.

Segundo José da Silva Pacheco, antes da habilitação o interessado não tem direito à cobrança da indenização, nem o transportador a obrigação de pagá-la. Segundo este autor, o credor que demandar o devedor antes de habilitar-se, ou seja, antes de vencida a dívida, fora dos casos em que a lei o permita, deverá esperar o tempo que restava para o vencimento, além de pagar as custas em dobro, conforme art. 1.530 do Código Civil.

Discordamos deste entendimento na medida em que a Constituição Federal de 1988 assegura que a lei não excluirá da apreciação pelo Poder Judiciário, lesão ou ameaça de direito. Ou seja, mesmo sem se habilitar extrajudicialmente, nada o impedirá de invocar a tutela jurisdicional para obter o ressarcimento dos prejuízos ocorridos.

Qualquer que seja o valor da indenização pleiteada com a finalidade de reparação de dano decorrente de acidente aéreo, a ação ajuizada terá o rito sumaríssimo, observando-se os arts. 276 a 281 do CPC. 
O foro competente para conhecer da ação de indenização, é segundo o art. 100, inciso V, alínea "a", § único do CPC, o do lugar do ato ou fato, ou ainda o do domicílio do autor, consoante estabelece o inciso I do art. 101 do CDC.

\subsection{A indenização no caso de dano ao passageiro}

Estabelece o art. 256 do CBA que o transportador responde pelo dano decorrente:

a) de morte ou lesão de passageiro, causada por acidente ocorrido durante a execução do contrato de transporte aéreo, a bordo de aeronave ou no curso das operações de embarque e desembarque; exceto se a morte ou a lesão resultar de culpa exclusiva do passageiro ou do seu estado de saúde.

Cabe esclarecer o que se entende por operação de embarque e desembarque. A operação de embarque é a que se realiza quando o passageiro já despachado no aeroporto, transpõe o limite de área destinada ao público em geral e entra na respectiva aeronave, abrangendo o percurso feito a pé, por meios mecânicos ou com a utilização de viaturas. Já a operação de desembarque inicia-se com a saída de bordo da aeronave e termina no ponto de intersecção da área interna do aeroporto e da área aberta ao público em geral. Encerra-se aí o período de execução do contrato de transporte, em que há obrigações recíprocas entre o passageiro e o transportador, principalmente no que se refere à responsabilidade civil.

Ressalte-se que a responsabilidade do transportador estende-se aos tripulantes, diretores e empregados que viajarem na aeronave acidentada, sem prejuízo da indenização devida em razão do acidente de trabalho; bem como àqueles passageiros gratuitos, que viajam por cortesia.

O dano resultante de morte de passageiro pode ser decorrente de:

a) homicídio doloso, quando não se aplicará o limite previsto no art. 248, ou seja, o tarifamento da indenização;

b) homicídio culposo, sendo neste caso perfeitamente aplicável o limite previsto no art. 257 , ou seja, a indenização tarifada. 
A indenização devida pelo transportador relativamente a cada passageiro e tripulante, limita-se no caso de morte ou lesão, ao valor correspondente na data do pagamento, a 3.500 (três mil e quinhentas) OTN.

Cabe-nos agora esclarecer quantos reais correspondem ao valor de uma Obrigação do Tesouro Nacional (OTN) nos dias atuais, a fim de que, através de exemplos práticos possamos estabelecer valores para as diversas hipóteses de indenização.

\subsection{A Obrigação Reajustável do Tesouro Nacional}

A Obrigação Reajustável do Tesouro Nacional - OTN, originou-se de nova denominação dada à antiga ORTN - Obrigação Reajustável do Tesouro Nacional, pelo Decreto-Lei $n^{\circ} 2.284$ de 10 de março de 1986 . O art. $6^{\circ}$ deste diploma legal estabeleceu que a partir de 03 de março de 1986 o seu valor seria de $\mathrm{Cz} \$ 106,40$ (Cento e seis cruzados reais e quarenta centavos). O $\S$ único deste mesmo artigo dispôs que em $1^{\circ}$ de março de 1987 seria procedido reajuste no valor da OTN em percentual igual à variação do IPC no período correspondente aos 12 (doze) meses imediatamente anteriores.

Com a entrada em vigor do Decreto-Lei ${ }^{\circ} 2.290$, de 21 de novembro de 1986 , seu art. $1^{\circ}$ alterou o contido no art. $6^{\circ}$ do Decreto-Lei $n^{\circ} 2.284 / 86$, estabelecendo que a OTN teria valor de Cz\$106,40 até 28/02/87. A partir de março de 1987, o critério de reajuste da OTN seria fixado pelo Conselho Monetário Nacional. Determinou o $\S$ único deste artigo $1^{\circ}$, que na atualização do valor nominal da OTN em $1^{\circ}$ de março de 1987 , seriam computadas as variações do IPC ocorridas até 30.11 .86 e o rendimento das Letras do Banco Central do Brasil, entre $1^{\circ}$ de dezembro de 1986 e $1^{\circ}$ de março de 1987.

Com a Lei $\mathrm{n}^{\circ} 7.730$, de 31 de janeiro de 1989 , através do disposto no inciso II do art. 15 , ficou estabelecida a extinção da OTN em $1^{\circ}$ de fevereiro de 1989, assegurando-se entretanto a liquidação dos títulos em circulação.

$\mathrm{O} \S 1^{\circ}$ do inciso II do art. 15 estabeleceu que o valor da OTN para a liquidação das obrigações decorrentes de mútuo, financiamento em geral e quaisquer outros contratos relativos a aplicações, inclusive financeiras, 
assumidas antes desta lei, a correção monetária seria calculada com base no valor de NCz\$6,17 (Seis cruzados novos e dezessete centavos) a OTN.

Com a entrada em vigor da Lei $n^{\circ} 7.747$, de 04 de abril de 1989 , seu art. $1^{\circ}$ estabeleceu que a liquidação de obrigações decorrentes de mútuo, financiamentos em geral e quaisquer outros contratos relativos a aplicações, inclusive no mercado financeiro, a correção monetária vinculada à OTN seria calculada, posteriormente ao mês de janeiro de 1989, com base no IPC, considerando-se a variação ocorrida a partir de fevereiro de 1989.

Esse sistemática de atualização vigorou até 31 de outubro de 1990 , quando a Lei $\mathrm{n}^{\circ} 8.088$ de 31/10/90 veio dispor de maneira diversa. A partir de 31 de outubro de 1990 , consoante dispôs o art. $1^{\circ}$ da Lei $n^{\circ} 8.088$, o valor nominal da OTN emitida anteriormente a 15 de janeiro de 1989 , seria atualizado no primeiro dia de cada mês, pelo Índice de Reajuste de Valores Fiscais-IRVF, divulgado pelo IBGE, consoante metodologia estabelecida em portaria do Ministro da Economia.

A sistemática de atualização da OTN instituída pelo art. $1^{\circ}$ da Lei $n^{\circ}$ $8.088 / 90$ foi ab-rogada pela Lei $n^{\circ} 8.177$, de $1^{\circ}$ de março de 1991 , que em seu art. $5^{\circ}$ determinou que a partir daquela data o valor nominal das Obrigações do Tesouro Nacional-OTN, emitidas anteriormente a 15 de janeiro de 1989, seria atualizado, no primeiro dia de cada mês, por índice calculado com base na TR referente ao mês anterior.

Com a edição da Lei $n^{\circ} 8.660$, de 28 de maio de 1993, o $§$ único do art. $3^{\circ}$ estabeleceu que o valor nominal dos títulos mencionados no art. $5^{\circ}$ da Lei n. 8.177, de 01/03/91 (OTN - BTN - TDA), seriam atualizados, no primeiro dia de cada mês, por índice calculado com base na Taxa Referencial - TR relativa ao dia primeiro do mês anterior.

Através da Portaria $n^{\circ}$ 640, de 22 de dezembro de 1993, do Ministério da Fazenda - o Secretário do Tesouro Nacional informou as condições gerais para o resgate das OTNs, estabelecendo, com fundamento nas leis acima referidas, que o coeficiente de atualização do valor de resgate das Obrigações do Tesouro Nacional seria de 352.023,80110196, no período de fevereiro de 1989 a janeiro de 1994 . Assim, temos que o valor de resgate da OTN no dia $1^{\circ}$ de janeiro de 1994 foi de $\mathrm{Cr} \$ 2.171,99$ (Dois mil, cento e setenta e hum cruzeiros reais e noventa e nove centavos). 
Para estabelecermos o valor da OTN do dia primeiro de abril de 1995 , basta seguirmos a orientação do $\S$ único do inciso II do art. $3^{\circ}$ da Lei $n^{\circ}$ 8.660 , de 28.05.93, último diploma legal de nosso conhecimento a disciplinar a matéria, que determina a atualização da OTN, no primeiro dia de cada mês, utilizando-se do índice calculado com base na Taxa Referencial - TR relativa ao dia primeiro do mês anterior.

Assim temos que se em janeiro/94 o valor da OTN correspondia a Cr\$2.171,99, e o índice diário da TR de primeiro janeiro/94 foi de 1,40865775 , temos que em janeiro/94 uma OTN correspondia a 12,153821TRs. Multiplicando-se esta quantidade de TRs correspondentes a uma OTN, pelo valor da TR de $1^{\circ}$ de abril de 1995 , temos $(12,153812$ TRs $x \mathrm{R} \$ 0,7267=\mathrm{R} \$ 8,832$ ).

Logo o valor da OTN de primeiro de abri1/95 é de aproximadamente $\mathrm{R} \$ 8,832$. 
Tabela Demonstrativa dos Valores da OTN consoante legislação

\begin{tabular}{|c|c|c|}
\hline Mês/Ano & Valor & Critério / Base Legal \\
\hline $03 / 86$ & $\mathrm{Cz} \$ 106,40$ & $\begin{array}{l}\text { Decreto-Lei } \quad \mathrm{n}^{\circ} \\
2.284 / 86\end{array}$ \\
\hline $02 / 89$ & $\mathrm{NCz} \$ 6,17$ & Lei $n^{\circ} 7.730 / 89$ \\
\hline $01 / 94$ & $\mathrm{Cr} \$ 2.171,99$ & $\begin{array}{l}\operatorname{Lei}^{\circ} 7.730 / 89, \text { Lei } \mathrm{n}^{\circ} \\
7.747 / 89, \text { Lei } \mathrm{n}^{\circ} \\
8.088 / 90, \text { Lei } \mathrm{n}^{\circ} \\
8.177 / 91, \text { Lei } \mathrm{n}^{\circ} \\
8.660 / 93 \text { e Portaria } \mathrm{n}^{\circ} \\
640, \text { de } 22.12 .93 \text { do } \\
\text { Ministério da Fazenda. }\end{array}$ \\
\hline $04 / 95$ & $\mathrm{R} \$ 8,832$ & Lei $n^{\circ} .8 .660 / 93$. \\
\hline
\end{tabular}

\subsection{Liquidação no caso de dano à vida}

No caso de acidente aéreo com morte de passageiro, ocorrido durante a execução do contrato de transporte, nos termos do art. 257, a indenização corresponerá a 3.500 OTN correspondentes ao valor em reais na data do pagamento. Assim teremos que matematicamente a indenização pode ser estabelecida através do seguinte cálculo: multiplicando-se 3.500 OTN $(3.500 \times \mathrm{R} \$ 8,832=\mathrm{R} \$ 30.912,00)$ teremos que o valor tarifado da indenização corresponderá hoje a (Trinta mil, novecentos e doze reais) por passageiro falecido em acidente aéreo ou vítima de lesões corporais. 


\subsection{Liquidação do dano no caso de atraso}

Em ocorrendo atraso no transporte aéreo contratado; exceto se ocorrer motivo de força maior ou comprovada determinação de autoridade aeronáutica que será responsabilizada, no caso de demora na partida por mais de 04 (quatro) horas, o transportador providenciará o embarque do passageiro em outro vôo que ofereça serviço equivalente para o mesmo destino, se houver, ou restituirá, de imediato, o valor do bilhete de passagem, hipótese em que haverá o rompimento do contrato de transporte pelo inadimplemento do transportador.

Assim, o portador de bilhete de passagem que deixar de embarcar no horário previsto no contrato, por excesso de passageiros, deverá ser embarcado pela empresa em outra aeronave, para o mesmo destino, em serviço executado pela própria empresa ou por outra, no prazo de quatro horas após a partida da aeronave para qual tinha a reserva confirmada.

Se a transportadora não tiver condições de embarcar o passageiro nesse período, deverá oferecer-lhe a opção de:

a) viajar em outro horário, após as quatro horas;

b) receber o reembolso do valor do bilhete.

Tratando-se de contrato bilateral o seu inadimplemento pode resultar perdas e danos, conforme art. 1.092 do CC. Ao prejudicado caberá invocar a tutela jurisdicional para pleitear a indenização, a qual é limitada a 150 OTN pelo CBA. Entretanto desde logo the é assegurado o direito a receber a devolução do valor da passagem.

Quando o transporte sofrer interrupção ou atraso em aeroporto de escala por período superior a quatro horas, qualquer que seja o motivo, o passageiro poderá optar pelo endosso do bilhete de passagem, ou seja, que a transportadora acomode-o em outra aeronave para o mesmo destino, ainda que em outra empresa; ou pela imediata devolução do preço correspondente ao segmento que ainda resta e que não foi cumprido. Eventuais despesas decorrentes da interrupção ou atraso de viagem, inclusive transporte de qualquer espécie, alimentação e hospedagem, correrão por conta do transportador contratual, sem prejuízo da indenização por responsabilidade civil a ser pleiteada em ação própria. A indenização neste caso de atraso do transporte limita-se da mesma forma a 150 OTN. 
Importante ressaltar que se o transporte aéreo for contratado com um transportador e executado por outro, o passageiro ou sucessores poderão demandar tanto o transportador contratual como o de fato, respondendo ambos solidariamente, seja caso de acidente ou de atraso.

Estabelece o $\S 2^{\circ}$ segundo do art. 257 do CBA, que no caso de a indenização ser fixada em forma de renda, o capital para a sua constituição não poderá exceder o maior valor previsto no art. 257 , ou seja, 3.500 OTN . $\mathrm{O} \S 1^{\circ}$ do art. 257 , ao disciplinar que nada impede seja fixado limite maior do que 150 OTN mediante pacto acessório entre o transportador e o passageiro, afigura-se-nos, pelas razões já expostas anteriormente, inteiramente compatível com o disposto nos arts. 25 e 51 do CDC, eis não se trata de atenuar a obrigação de indenizar, mas ao contrário, de estabelecer cláusula contratual com valores indenizatórios mais benéficos para o consumidor, acima dos montantes previstos em lei, dado que o CDC não proíbe o tarifamento da indenização decorrente de lei, mas sim a atenuação, a exoneração da responsabilidade. Limitar o valor da reparação, do ressarcimento dos danos, não é o mesmo que impossibilitar, atenuar, ou exonerar.

No caso de atraso do transporte aéreo do qual adveio prejuízo ao passageiro, teremos o valor de 150 OTN $x$ R $\$ 8,832=\mathrm{R} \$ 1.324,80$ (Hum mil, trezentos e vinte e quatro reais e oitenta centavos) por passageiro.

\subsection{A indenização no caso de danos à bagagem}

Importante salientar desde o início que o termo bagagem não se confunde com carga, a qual é disciplinada em seção especial do CBA.

O valor da indenização devida pelo transportador no caso de destruição, perda ou avaria de bagagem despachada ou conservada em mãos do passageiro, ocorrida durante a execução do contrato de transporte aéreo, limita-se consoante estabelece o art. 260 do CBA ao valor de 150 OTN por ocasião do pagamento, em relação a cada passageiro.

Para que haja direito à indenização é necessário:

a) a destruição, perda ou avaria ocorrida durante a execução do contrato de transporte;

b) haja o protesto do passageiro;

R. Fac. Direito. Curitiba, a.27, n.27, 1992/93, p.103-139 
c) não ocorra exoneração de responsabilidade do transportador;

d) haja habilitação ou comprovação de legitimidade.

Excepcionalmente, nas hipóteses em que houver uma bagagem ou bem de valor declarado, poderão as partes, mediante o pagamento de uma taxa suplementar, ajustar outro valor no caso de perda extravio ou desaparecimento do volume, prevalecendo então o valor do seguro pelos novos limites contratados, o que pelas razões já expendidas também não confronta com dispositivos do Código do Consumidor.

O CB A não esclarece se a indenização é devida relativamente a cada bagagem despachada ou a todas que o passageiro estiver a utilizar, entretanto acredita-se que o valor de 150 OTN seja devido por passageiro, independentemente do número de volumes que esteja a levar como bagagem.

Da mesma forma, o CBA manda aplicar à disciplina da indenização pelo extravio de bagagem o que couber relativamente à disciplina da indenização no caso de dano à carga. Caberia então a formulação das seguintes indagações:

1 - Pode haver indenização no caso de dano resultante de atraso na entrega da bagagem?

2 - Como se aplica a sistemática do art. 262 do CB A, se a indenização por dano à bagagem é regulada de forma diversa, art. 260 ?

3 - Aplica-se o art. 266 ou o art. 258, relativamente a ação por dano à bagagem?

Em resposta a essas indagações José da Silva Pacheco ${ }^{7}$ nos esclarece, respectivamente:

1.1. Não cogitando o art. 260 de indenização em razão de atraso na entrega de bagagem, e dispondo o art. $257,2^{a}$ parte que a responsabilidade do transportador em relação a cada passageiro, limita-se em se tratando de atraso do transporte do passageiro e sua bagagem, ao valor correspondente a 150 OTN, não poderá haver responsabilidade do transportador por valor superior a este.

7 José da Silva Pacheco, Comentários..., op. cit., p. 522 e ss. 
2.2. Não deve ser confundida a sistemática do art. $262 \mathrm{com}$ a do art. 260 do CBA. Aplica-se o art. 257 no caso de atraso do transporte do passageiro ou da bagagem que o acompanha, quer se trate de bagagem de mão ou despachada.

3.3. Não há que se aplicar o art. 262 em se tratando de bagagem, despachada ou de mão, porque neste caso não se cogita de expedidor e destinatário, que se refere exclusivamente à carga.

No caso de passageiro que levava 03 volumes de bagagem e apenas dois deles foram extraviados, teremos: 150 OTN $x$ R $\$ 8,832=\mathrm{R} \$ 1.324,80$ (Hum mil, trezentos e vinte e quatro reais e oitenta centavos) por passageiro.

\subsection{A indenização no caso de danos à carga}

Conhecimento de carga é o instrumento ou o comprovante material do contrato de transporte aéreo de carga. Ele evidencia a conclusão do contrato bem como o recebimento da carga pelo transportador para conduzila a determinado aeroporto, assim como as condições do transporte.

Geralmente quem o emite é o transportador por conta e em nome do expedidor a seu pedido, cabendo ressaltar entretanto que a obrigação de emitir o conhecimento é do expedidor.

Quando houver mais de um volume pode haver conhecimentos distintos (art. 238). Isso é justificável na medida em que uma empresa tem diversas aeronaves e diversos vôos, em qual destas ou daqueles será transportada a mercadoria é problema interno da transportadora. Assim, se forem vários volumes entregues pelo expedidor, tem o transportador o direito de exigir que the sejam entregues tantos conhecimentos quantos sejam os volumes, e o expedidor tem a obrigação de fornecê-los.

O expedidor responde pela exatidão das indicações e declarações constantes do conhecimento aéreo e pelo dano que em conseqüência de suas declarações irregulares, inexatas ou incompletas vier a sofrer o transportador ou qualquer outra pessoa. A responsabilidade de que se está a cogitar é a responsabilidade civil, de origem contratual, embora resulte de ato ilícito. Por outro lado não está o transportador obrigado a conferir e averiguar a veracidade das declarações, nem verificar se são suficientes os documentos apresentados, o que não significa não possa recusar mercadoria

R. Fac. Direito, Curitiba, a.27, n.27. 1992/93. p.103-139 
desacompanhada de documentos indispensáveis ao transporte exigidos por lei.

O expedidor poderá propor ação contra o primeiro transportador e contra aquele que haja efetuado o transporte, durante o qual ocorreu o dano, e o destinatário contra este e contra o último transportador. Há a solidariedade entre os transportadores responsáveis perante o expedidor e o destinatário.

No caso de execução do contrato em que foi usado outro meio de transporte, e houver dúvida sobre onde ocorreu o dano, a responsabilidade do transportador será regida pelo CBA. Ou seja, se para a execução do contrato de transporte aéreo efetuar-se qualquer tipo de transporte terrestre, para carregamento, entrega ou baldeação, presume-se que o dano resultou de fato ocorrido durante a execução de transporte aéreo, salvo prova em contrário.

O transportador aéreo exime-se da responsabilidade no caso de vício da própria mercadoria, embalagem defeituosa da carga, ato de guerra ou conflito armado, ato de autoridade pública referente à carga.

No caso de ocorrer dano somente em alguns dos volumes compreendidos no conhecimento de transporte aéreo, somente será considerado para efeito de indenização o peso dos volumes perdidos, deteriorados ou entregues com atraso. Por isso é importante quando da emissão do conhecimento, consignar com exatidão o peso de cada volume.

Interessante notar que o conhecimento aéreo de transporte de carga faz presumir, até prova em contrário, a conclusão do contrato, o recebimento da carga e das condições do transporte.

Igualmente presume-se entregue em bom estado e de conformidade com o conhecimento, a carga que o destinatário receber sem protesto. $\mathrm{O}$ protesto é feito mediante ressalva lançada no documento de transporte conhecimento - ou mediante comunicação escrita encaminhada ao transportador.

O CBA estabelece o prazo de 7 dias a contar do recebimento para protesto no caso de avaria. O protesto por atraso deverá ser feito dentro de 15 dias a contar da data em que a carga tenha sido colocada à disposição do destinatário, ou seja, do dia em que chegar a mercadoria ao aeroporto de 
destino e estiver em condições de poder ser entregue ao destinatário. Importante ressaltar que na falta do protesto, qualquer ação somente será admitida se fundada no dolo do transportador.

Em caso de transportador sucessivo ou de transportador de fato, o protesto será encaminhado aos responsáveis. Ou seja, tanto o transportador contratual quanto o transportador de fato poderão ser demandados, respondendo ambos solidariamente perante o expedidor e o destinatário.

Se não houver protesto tempestivo, não se poderá pleitear a indenização posterior, porque o recebimento da carga sem protesto faz presumir que a entrega se deu em bom estado, exceto se provar o dolo do transportador como explanado anteriormente.

A execução do contrato de transporte aéreo de carga inicia-se com o recebimento do bem e persiste durante o período em que se encontre sob a responsabilidade do transportador, seja em aeródromo, em aeronave, em qualquer lugar no caso de aterrissagem forçada, até a entrega final.

Estabelece o CBA que no caso de atraso, perda, destruição ou avaria de carga, ocorrida durante a execução do contrato de transporte aéreo, a responsabilidade do transportador limita-se ao valor correspondente a 3 OTN por quilo, salvo se for feita declaração especial pelo expedidor e mediante o pagamento de uma taxa suplementar, se for o caso.

A título exemplificativo, podemos ilustrar a seguinte situação: empresa do ramo de aparelhos e equipamentos cirúrgicos situada em São Paulo remete para o Hospital de Clínicas de Curitiba, via aérea, com regular emissão de conhecimento aéreo de transporte vinte e cinco caixas de papelão contendo 40 unidades de máscaras para inalação cada uma, num peso de $3,25 \mathrm{Kg} /$ caixa, mercadoria acompanhada de nota fiscal no valor de $\mathrm{R} \$ 8.750,00$.

Cinco caixas da mercadoria são extraviadas pelo transportador aéreo no aeroporto de São Paulo. Teremos então uma indenização estabelecida da seguinte maneira.

Cada caixa pesava $3,25 \mathrm{~kg}$ × 5 unidades perdidas $=16,25 \mathrm{~kg}$ perdidos. 3 OTN $/ \mathrm{kg} \times \mathrm{R} \$ 8,832=\mathrm{R} \$ 26,49 / \mathrm{kg} \times 16,25 \mathrm{~kg}=\mathrm{R} \$ 430,56$ (Quatrocentos e trinta reais e cinqüenta e seis centavos). 
Como o preço unitário de cada máscara corresponde a $\mathrm{R} \$$ $8.750,00 / 25 \mathrm{vol}=\mathrm{Cr} \$ 350,00 / \mathrm{vol} / 40=\mathrm{R} \$ 8,75$. Teremos que o prejuízo virtual do expedidor foi de $\mathrm{Cr} \$ 8,75 \times 200$ máscaras $=\mathrm{R} \$ 1.750,00$, sendo que a empresa aérea somente é obrigada a indenizar $\mathrm{R} \$ 430,56$. Verifica-se que o prejuízo real do expedidor foi de $\mathrm{R} \$ 1.319,44$, razão pela qual se conclui deveria ter sido pactuado contrato de seguro exclusivo relativamente à mercadoria despachada.

\subsection{A indenização no caso de serviço aéreo gratuito}

No caso de transporte aéreo gratuito não há contrato de transporte, eis que o art. 222, §único prevê o pagamento para a formação do contrato. Entretanto, se houver inexistência do contrato de transporte, e se ocorrerem danos durante a execução de serviços aéreos, o transportador responde consoante determina o art. 267 do CBA. No caso de serviço aéreo privado ou público o transportador responde perante o pessoal técnico de bordo, perante os passageiros gratuitos que viajarem por cortesia, e pelos danos causados às pessoas e bens na superfície, nos limites previstos no art. 257 e parágrafos, ou seja, 3.500 OTN.

No caso de transporte aéreo gratuito realizado pelo Correio Aéreo Nacional, não haverá indenização por danos à pessoa ou à bagagem a bordo, salvo se houver comprovação de culpa ou dolo dos operadores da aeronave, art. 267, inciso III. No caso de culpa a indenização sujeita-se aos limites do art. 257 e 260 . No caso de dolo, a indenização não estará sujeita aos limites do CBA, mas é devida nos termos da legislação comum.

A exclusão, no caso de transporte gratuito pelo Correio Aéreo Nacional, de qualquer possibilidade de indenização caso a vítima ou os seus sucessores não comprovem culpa ou dolo dos tripulantes no exercício de suas funções, parace-nos injusta. Trata-se portanto, de verdadeiro tratamento diferenciado para o transporte gratuito realizado pelo Correio Aéreo Nacional em relação ao transporte gratuito realizado por empresa privada., o que se nos afigura contraditório com o princípio da isonomia constitucionalmente consgrado.

Interessante notar que as aeronaves destinadas a serviços aéreos privados, sem fins comerciais, que efetuarem serviços aéreos de transporte 
público, não prevalecem os limites de indenização previstos no $\mathrm{CBA}$, conforme art. 178 .

Da mesma forma, as pessoas físicas ou jurídicas autorizadas a exercer atividade de fomento ou desportiva, assim como o adestramento de tripulantes, não poderão realizar serviço público de transporte aéreo, com ou sem remuneração. No caso de violação não se aplicarão os limites tarifários previstos no CBA para o estabelecimento da indenização.

\subsection{A indenização para com terceiros na superfície}

Consoante disciplina o art. 268 do CBA, o explorador da atividade aeronáutica responde pelos danos a terceiros na superfície, causados diretamente por aeronave em vôo ou manobra, assim como por pessoa ou coisa dele caída ou projetada.

São elementos para a incidência do art. 268:

a) a existência de danos causados diretamente por aeronave em vôo ou manobra;

b) por pessoa ou coisa caída de aeronave em vôo ou manobra.

Pouco importa que a coisa tenha se desprendido ou caído da aeronave, tal como turbina, porta, asa, ou se dela foi projetada ou atirada. A aeronave é tida em vôo desde o momento em que a força motriz é aplicada para decolar até o momento em que termina a operação de pouso.

Os danos podem ser causados a pessoas ou coisas em terra, na água (mar, rio, lago) ou na superfície.

Nesta hipótese são causas excludentes da responsabilidade de indenizar: fatos;

a) a ausência de relação direta de causa e efeito entre o dano e os

b) se resultar apenas de passagem da aeronave pelo espaço aéreo, seguindo todas as normas de tráfego aéreo;

R. Fac. Direito, Curitiba, a.27, n.27, 1992/93, p.103-139 
c) se provar que os danos resultaram exclusivamente de culpa da pessoa que os tenha sofrido ou de seus prepostos;

d) se a aeronave for operada por pessoa estranha que dela se apoderou, contra a vontade do explorador ou de seus prepostos.

Nos demais casos a responsabilidade do explorador limita-se de acordo com o peso da aeronave estabelecido no certificado de aeronavegabilidade ou documento equivalente, a saber:

I - aeronave com peso máximo de $1.000 \mathrm{~kg}-3.500 \mathrm{OTN}$

II - aeronave com peso superior a $1.000 \mathrm{~kg}-3.500 \mathrm{OTN}+1 / 10$ OTN por quilograma que exceder a $1.000 \mathrm{~kg}$.

No caso de danos para com terceiro na superfície, o explorador deverá pagar aos prejudicados habilitados $30 \%$ da quantia máxima a que estará obrigado, dentro de 60 dias a partir da ocorrência do fato.

O saldo de $70 \%$ será rateado entre todos os prejudicados habilitados, quando após o decurso de 90 dias do fato, não pender de processo de habilitação ou ação de reparação de danos.

Quando a importância total das indenizações exceder o limite de responsabilidade estabelecido acima, serão aplicadas as seguintes regras:

a) havendo apenas danos pessoais ou apenas materiais, as indenizações serão reduzidas aos respectivos montantes;

b) havendo danos materiais e pessoais, metade da importância correspondente ao limite máximo de indenização será destinada a cobrir cada espécie de dano, se houver saldo, será usado para complementar indenizações que não tenham podido ser pagas integralmente.

Estes limites não prevalecerão no caso de dolo ou culpa grave do explorador ou prepostos, o dano for causado pela aeronave no solo com os motores parados, e o dano seja causado por quem esteja operando ilegal ou ilegitimamente a aeronave.

Conforme José da Silva Pacheco, havendo prejuízos a pessoas ou coisas, a primeira providência será:

a) verificar a ocorrência do prejuízo e apurar o seu valor efetivo, habilitando-se os interessados; 
b) quantificar a empresa transportadora ou seguradora, o limite máximo em relação ao peso da aeronave.

Se houver danos pessoais, apuram-se os seus efetivos valores. Se não ultrapassar o montante limitativo previsto no art. 269, efetua-se o pagamento. Se exceder aqueles limites, reduzem-se os valores das indenizações, proporcionalmente, até enquadrar-se no teto do art. 269. Procede-se da mesma forma no caso de danos materiais de modo a respeitar o limite legal.

No caso de haver danos pessoais e materiais, excedendo-se o limite do art. 269, a metade da importância máxima prevista será aplicada para os prejuízos às pessoas e a outra metade aos danos aos bens.

Contudo, se houver saldo de uma metade em relação à outra, aplicase para suplementar as indenizações que não tenham sido pagas com a integralidade da outra metade (art. 271).

Percebe-se portanto, que no caso de danos a pessoas ou bens na superfície, o limite do art. 269 é o máximo que pode ser pago pelo explorador e que deve ser utilizado na sua integralidade para atender as indenizações efetivamente apuradas e devidas.

A título meramente ilustrativo, aventamos a seguinte hipótese: um avião bimotor Brasília prefixo PT-0989 de uma Empresa de Taxi Aéreo, realiza um pouso de emergência na plantação de milho e feijão do Sr. Paulo Pereira, destruindo $2.000 \mathrm{~m} 2$ de plantação, bem como causando a morte de seu funcionário que realizava pulverização de herbicida no local.

De acordo com o certificado de aeronavegabilidade do aparelho, o peso autorizado para decolagem corresponde 10.500 quilogramas.

Conforme o art. 269, o teto da indenização corresponderá à importância de, matematicamente: 3.500 OTN $x \mathrm{R} \$ 8,832=\mathrm{R} \$ 30.912,00$. A este valor deve ser acrescido de $1 / 10 \times \mathrm{R} \$ 8,832=\mathrm{R} \$ 0,8832$ por $\mathrm{kg}$ excedente a $1.000 \mathrm{~kg}$. Temos de excedente $9.500 \mathrm{~kg}$. Logo $9.500 \times \mathrm{R} \$ 0,8832=\mathrm{R} \$$ $8.390,40$.

O teto da indenização a ser paga ao seu Paulo Pereira e herdeiros de seu funcionário corresponderá a R \$39.302,40 (Trinta e nove mil, trezentos e dois reais e quarenta centavos).

R. Fac. Direito. Curitiba, a.27, n.27. 1992/93, p.103-139 
Apurados os montantes dos danos materiais e pessoais, verificou-se que o dano material efetivo corresponde a $\mathrm{R} \$ 8.000,00$ (Oito mil reais), já o dano pessoal efetivo foi de $\mathrm{R} \$ 80.0000,00$ (Oitenta mil reais).

Aplicando-se o contido no art. 271, parte-se da divisão do total de $\mathrm{R} \$ 39.302,40$. Metade é utilizada para o ressarcimento dos danos materiais ( $\mathrm{R} \$ 19.651,20)$, e a outra metade para o ressarcimento dos danos pessoais ( $\$$ \$ 19.651,20), pelo que teremos o seguinte quadro:

\begin{tabular}{|c|c|}
\hline DANOS MATERIAIS & DANOS PESSOAIS \\
\hline EFETIVOS: + R $\$ 8.000,00$ & EFETIVOS: + R\$80.000,00 \\
\hline INDENIZ : - R\$ $19.651,20$ & INDENIZADO: - R\$19.651,20 \\
\hline DIFERENÇA: R\$11.651,20 & DIFERENÇA: + R $\$ 60.348,80$ \\
\hline SALDO: $\mathrm{R} \$ 11.651,20$ & IND.COMPLEM: R\$ $11.651,20$ \\
\hline PREJUÍZO FINAL: ZERO & PREJUÍZO FINAL: + R\$ 48.697,60 \\
\hline
\end{tabular}

Da análise do quadro acima, verifica-se que no caso dos herdeiros da vítima falecida, houve um prejuízo efetivo de $R \$ 48.697,60$ ocorrido justamente em razão do tarifamento da indenização e à estrita obediência às regras dos incisos do art. 271 do CBA. A indenização pelo dano então não é completa, integral.

\subsection{A indenização no caso de Abalroamento}

Considera-se proveniente de abalroamento o dano decorrente da colisão de 2 ou mais aeronaves, em vôo ou em manobra na superfície, e os produzidos às pessoas ou coisas a bordo, por outra aeronave em vôo, conforme art. 273 do CBA. 
Neste caso a responsabilidade pelo ressarcimento dos danos, consoante estabeleceu o CBA, incumbe ao explorador ou proprietário causador dos prejuízos, seja em decorrência de utilização própria da aeronave ou através de seus prepostos.

$\mathrm{O}$ artigo trata portanto, dos prejuizos decorrentes:

a) da colisão de duas ou mais aeronaves em movimento no espaço aéreo ou nos aeroportos;

b) de uma aeronave em vôo sobre outra também em vôo, ainda que não tenha havido colisão;

c) de colisão de aeronaves ou de duas ou mais aeronaves conjunta ou separadamente.

Os prejuízos oriundos de uma colisão podem ser:

a) os causados a pessoas e coisas a bordo das aeronaves envolvidas;

b) decorrentes dos danos sofridos pelas aeronaves envolvidas;

c) os prejuízos sofridos pela privação do uso da aeronave abalroada;

d) às pessoas e bens na superfície.

e) as despesas judiciais, assumidas pelo explorador da aeronave abalroada em conseqüência do evento danoso.

No caso de culpas concorrentes, a responsabilidade é solidária, proporcional à gravidade da falta. Em sendo impossível estabelecer a proporcionalidade da falta, cada um dos exploradores responderá em partes iguais.

O abalroamento pode ser decorrente:

a) de caso fortuito ou força maior;

b) doloso, excluindo-se qualquer limitação à indenização;

c) culposo, em que se atribui o ônus ao culpado; dos ônus,

d) de culpa concorrente, quando há culpa recíproca, com a divisão

e) de culpa duvidosa, em que se dividem os encargos. 
Importante ressaltar que a responsabilidade civil causada por abalroamento é de natureza extracontratual, ou seja, os danos relativos à aeronave e os seus lucros cessantes. De outro lado há os danos relativos às pessoas e coisas à bordo que são de natureza contratual.

Nestes casos a indenização não excederá aos limites estabelecidos nos arts. 257,260 e 262, relativos a pessoas, coisas a bordo, elevados ao dobro. A terceiros na superfície, fixados nos termos do art. 269 em dobro. Ao valor dos reparos e substituições de peças da aeronave abalroada, se recuperável, ou de seu valor real imediatamente anterior ao evento, se inconveniente ou impossível a recuperação. Ao décimo do valor real da aeronave danificada em razão da privação do seu uso normal.

Não vigorarão estes limites se:

a) o abalroamento resultar de dolo ou culpa grave do explorador ou prepostos;

b) se o explorador ou prepostos concorreram para o dano em razão de ação ou omissão violadora de normas sobre tráfego aéreo. Desse modo, se houver culpa específica por infração de normas vigentes de tráfego aéreo, não se aplicam os limites do art. 277, sendo ilimitada a responsabilidade, que se pautará pelo Código Civil;

c) se o abalroamento for decorrência de apossamento ilícito ou uso indevido de aeronave, sem negligência do explorador ou prepostos os quais ficarão eximidos de responsabilidade, conforme art. 279 do CBA.

Importante salientar o contido no $\S$ único do art. 279 do CBA, eis que a pessoa que sofrer danos, ou os seus beneficiários, terão direito a ser indenizados, até a soma dos limites correspondentes a cada uma das aeronaves, mas nenhum explorador será responsável por soma que exceda os limites aplicáveis às suas aeronaves, salvo se a sua responsabilidade for ilimitada, por ter sido provado que o dano foi causado por dolo ou culpa grave, conforme $\S 1^{\circ}$ do art. 248 do CBA.

$\mathrm{Da}$ análise do texto legal, verifica-se que as indenizações devidas relativamente a cada uma das aeronaves podem ser somadas para o ressarcimento dos danos, mas nenhum explorador será responsável por soma que exceda os limites aplicáveis a sua aeronave. 
Imaginemos a seguinte situação hipotética: $\mathrm{O}$ avião Cesna, monomotor prefixo PP-009N87, de propriedade de uma empresa de Taxi-Aéreo realizava procedimento para decolagem na pista no aeroporto de Blumenau quando foi abalroado pela aeronave Bandeirante prefixo PT-09MJ de propriedade de um fazendeiro da região, o qual era comandado por um piloto novato que por desobediência à orientação da torre de comando, também dirigia-se para a cabeceira da pista para decolagem.

Em decorrência da colisão o "avião inocente" ficou completamente destruído em razão de incêndio, mas o seu piloto e os dois únicos passageiros conseguiram ser retirados da aeronave com vida, embora com lesões corporais de natureza grave.

As bagagens e duas caixas (carga) de $15 \mathrm{~kg}$ cada uma ficaram completamente destruídas.

1.1) No caso de danos às pessoas a bordo aplica-se a indenização de 3.500 OTN $\times \mathrm{R} \$ 8,832=\mathrm{R} \$ 30.912,00 \times 3$ vítimas $\times 2$ (dobro) $=\mathrm{R} \$ 185.472,00$.

1.2) No caso de danos à bagagem dos dois passageiros temos a quantia de 150 OTN $x \mathrm{R} \$ 8,832 \times 2$ passageiros $\times 2$ (dobro) $=\mathrm{R} \$ 70.656,00$.

1.3) No caso do dano à carga teremos 3 OTN x $R \$ 8,832 \times 30 \mathrm{~kg} \mathrm{x}$ $2($ dobro $)=\mathrm{R} \$ 1.589,76$.

2) O valor da aeronave abalroada (incendiada) imediatamente anterior ao evento correspondia a $\mathrm{R} \$ 250.000,00$.

3) Em razão da privação do uso normal da aeronave até a aquisição de outra (lucros cessantes): $\mathrm{R} \$ 250.000,00 / 10=\mathrm{R} \$ 25.000,00$.

O total da Indenização devida pelo fazendeiro será de $\mathrm{R} \$ 532.717,76$.

\section{A responsabilidade do construtor aeronáutico e das entidades de infra-estrutura aeronáutica}

No que se refere à responsabilidade do contrutor de produto aeronáutico, em relação aos danos decorrentes de defeitos de fabricação, da administração de aeroportos e administração pública, em serviços de infra-estrutura, por culpa de seus operadores, em acidentes que causem

R. Fac. Direito, Curitiba, a.27, n.27, 1992/93. p.103-139 
danos a passageiros ou coisas, dispõe o CBA no art. 280 que aplicam-se conforme o caso os arts. 257, 260, 262, 269 e 277.

Ou seja, conforme estes dispositivos, vigorariam os mesmos limites de indenização (tarifamento) anteriormente explanados, seja para o construtor de produtos aeronáuticos por defeitos de fabricação (fato do produto), seja para a administração (fato do serviço).

Resta-nos esclarecer se face ao que estabelece o Código de Proteção ao Consumidor, no Capítulo IV, Seções I, II e III, que disciplinou a qualidade dos produtos e serviços, da prevenção e da reparação de danos, ainda prevalece o contido no art. 280 do CBA.

No art. 12 do CDC ficou expressamente estabelecido que o fabricante, o produtor, o construtor nacional ou estrangeiro, e o importador, respondem independentemente da existência de culpa, pela reparação dos danos causados aos consumidores por defeitos decorrentes de projeto, fabricação, construção, montagem, fórmulas, manipulação, apresentação ou acondicionamento de seus produtos, bem como por informações insuficientes ou inadequadas sobre sua utilização e riscos.

Da leitura deste dispositivo legal acerca da responsabilidade pelo fato do produto, verifica-se que a responsabilidade do construtor e do prestador de serviços aeronáuticos é objetiva, ou seja, independe da apuração da culpa, bastando a efetividade do dano e o nexo causal entre o defeito do produto e a lesão.

De acordo com Antônio Hermen de Vasconcellos e Benjamin ${ }^{8}$, ao tecer comentários aos artigos 12 e 14 do $\mathrm{CDC}$, o dever de indenizar estatuído no Código do Consumidor é integral, pelo que a indenização deve ser a mais completa possível. Razão pela qual, para este autor, as hipóteses de responsabilidade civil tarifada, em sede de acidente de consumo, previstas para certos serviços, e no presente caso para o serviço de transporte aéreo, estariam totalmente afastadas pelo novo texto legal, exceto se se tratar de pura relação jurídica comercial, hipótese em que o CDC não se aplica.

Conforme exposição anterior a que se reporta, não é possivel concordar com a afirmativa deste autor, no que refere à não existência de limites

8 Antônio Hermen de Vasconcelos e Benjamin, Comentários ao Código de Proteção ao Consumidor, Coordenação de Juarez de Oliveira, São Paulo, Saraiva, 1991, p. 78 
à indenização no caso de responsabilidade civil decorrente do contrato de transporte aéreo de passageiros, cargas e bagagens.

No que se refere à responsabilidade do construtor aeronáutico, também não se concorda com as razões deste mesmo autor, uma vez que o CDC, ao instituir a responsabilidade objetiva do construtor aeronáutico e do prestador de serviços, não impossibilitou o tarifamento da indenização pela lei, proibiu-o apenas em relação às partes contratantes de o fazerem abaixo dos limites legais.

Verifica-se que o contido no art. 280 do CBA ainda se aplica ao construtor aeronáutico e às entidades prestadoras de serviços de infra-estrutura e administração dos aeroportos, uma vez que a responsabilidade objetiva, independente de culpa, instituida pelo $C D C$, não impede que o legislador estabeleça limitação ao valor da indenização. Tal proibição impõe-se ao pactuado pelas partes em contrato à parte, cujo tarifamento não pode estipular valor inferior ao estabelecido em lei. Não há no $\mathrm{CDC}$, dispositivo legal que impeça ou mesmo tenha revogado o tarifamento da indenização estabelecida em face de lei anterior, na hipótese o CBA.

\section{A garantia da responsabilidade e respectiva indenização}

Como garantia de responsabilidade todo explorador é obrigado a contratar seguro para eventual indenização de riscos futuros em relação aos itens enumerados no art. 281 do CBA. O explorador de aeronave estrangeira deverá apresentar garantias iguais ou equivalentes às exigidas das aeronaves brasileiras, bem como o cumprimento das normas estabelecidas em Convenções ou Acordos Internacionais.

A concessão e renovação do certificado de aeronavegabilidade só será possivel com a apresentação do comprovante de seguro, o qual será averbado no respectivo certificado, ficando entretanto suspensa a validade do certificado de aeronavegabilidade se o pagamento do seguro não for efetuado. O seguro obrigatório cuja expiração ocorrer em vôo considera-se prorrogado até o seu término. Visa-se com isso proteger os usuários e terceiros, em relação à aeronave em vôo. Entretanto, relativamente ao seguro, são nulas as cláusulas das apólices que:

R. Fac. 1)ircito. Curitiba, a.27. 11.27. 1992/93, p.103-139 
a) excluam riscos resultantes do transporte aéreo;

b) excluam a responsabilidade do transportador aéreo;

c) estabeleçam limite de indenização inferior ao previsto no CBA.

\section{A responsabilidade no transporte aéreo internacional}

No que se refere a responsabilidade civil no transporte aéreo internacional, estabelece o art. 287 do CBA que para efeito de limite de responsabilidade civil, as quantias estabelecidas nas Convenções Internacionais de que o Brasil faça parte serão convertidas em moeda nacional, na forma de regulamento expedido pelo Poder Executivo.

A Convenção de Varsóvia em seu art. 22 , item $n^{\circ} 1$ estabelece que a responsabilidade por morte ou lesões corporais limita-se à importância de 125.000 francos por passageiro.

No caso de dano à mercadorias e bagagem despachada, a responsabilidade limita-se a 250 francos por quilograma, salvo declaração especial ou seguro mediante pagamento de taxa suplementar.

Já quanto aos objetos que o passageiro conservar sob sua guarda, limita-se a indenização ao valor correspondente a 5.000 francos por viajante.

O item 4 do art. 22 , a referida convenção prescreve que o franco utilizado é o franco francês, constituído de 65,5 miligramas de ouro, a título de novecentos milésimos de metal fino, que devem ser convertidos em moeda nacional de cada país.

\section{Conclusão}

Em razão de todo o exposto, compartilha-se do posicionamento de Luis Camargo Pinto de Carvalho ${ }^{9}$, que também sustenta que os princípios que disciplinam o Direito Aeronáutico, notadamente o que se refere ao tarifamento da indenização -limitando a responsabilidade do transportador

9 Luís Camargo Pinto de Carvalho, "O Código do Consumidor e o Direito Aeronáutico", Revista dos Tribunais, 1991(673), p. 47.

R. Fac. Direito, Curitiba, a.27, n.27, 1992/93, p.103-134

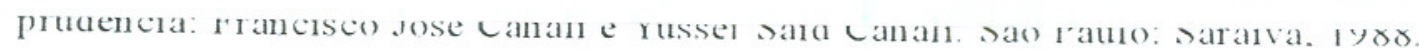

NASCIMI:NT(). Tupinambá Miguel Castro do. Responsabilidade Civil no ('ódigo do ('onsumidor: Rio de Janciro: ^ide. 1991.

PACHEC(). José da Silva. ('omentários ao ('ódigo Brasileiro de deronántica. Rio de Jan eiro: Forense. 1990.

SAIJ.FS. Marcos Paulo de Almeida. O Consumidor é o Sistema Financeiro. (L'm Comentário à Lei 8.07890). São Paulo: Acadèmica. 1991.

VASCONCELLOS E BENJAMIN. Antònio Hermen de. Coméntários ao código de Proteção ao ('onsumidor: Coordenador Juarez de ()liveira. São Paulo: Saraiva. 1991. 